\title{
3. TRACE ELEMENT AND ISOTOPIC CHARACTERISTICS OF KERGUELEN-HEARD PLATEAU BASALTS 1
}

\author{
Vincent J. M. Salters, ${ }^{2}$ Michael Storey, ${ }^{3}$ James H. Sevigny, ${ }^{4}$ and Hubert Whitechurch ${ }^{5}$
}

\begin{abstract}
During Leg 120 basalts were recovered at four drill holes on the Kerguelen-Heard Plateau. This paper reports the trace element and $\mathrm{Sr}, \mathrm{Nd}, \mathrm{Hf}$, and $\mathrm{Pb}$ isotopic characteristics of these basalts and compares these basalts with Indian Ocean basalts and Kerguelen and Heard island volcanics. Kerguelen-Heard Plateau basalts are extremely heterogeneous in character. Intersite variations are larger than intrasite variations. Part of the chemical variations of the plateau volcanics overlap with those characteristics of Kerguelen Island volcanics, which indicates tapping of the same mantle source during the two different periods of activity. The estimates of the degree of melting for the plateau basalts (smaller degree of melting than for mid-ocean ridge basalts) and the heterogeneous character of the plateau exclude an origin that requires large degrees of melting or more rigorous convection than acean ridges. However, all characteristics indicate an oceanic origin for the Kerguelen-Heard Plateau.
\end{abstract}

\section{INTRODUCTION}

The northeast-trending Kerguelen-Heard Plateau (KHP), with $3 \times 10^{6} \mathrm{~km}^{2}$ (almost six times the size of France), is the second largest submarine feature (the Ontong-Java Plateau with $4 \times 10^{6} \mathrm{~km}^{2}$ is larger). Here we report the results of major, trace, and isotopic analyses of the volcanics in the four Leg 120 drill holes that cored basalt and compare these results with analyses from Kerguelen Island. Given the size of the KHP, this study can only be considered as exploratory.

Figure 1 shows the bathymetry of the KHP and indicates the drill sites of Leg 119 and 120. Based on bathymetry, the Kerguelen Plateau has been divided into northern and southern sectors (Schlich, 1975). The northern part, located between $46^{\circ} \mathrm{S}$ and $55^{\circ} \mathrm{S}$, generally lies in water depths of $<1000$ $\mathrm{m}$ and contains the Eocene to Quaternary volcanic islands of Kerguelen and Heard. The boundary between the northern and southern sector is a northwest-trending zone of complex bathymetry in which the east-trending Elan Bank is the main feature. The southern part of the plateau between $57^{\circ}$ and $64^{\circ} \mathrm{S}$ generally lies deeper, between 1500 and $2000 \mathrm{~m}$. Furthermore, in comparison with the northern part of the plateau, the southern part appears to have a simpler structure and a less pronounced gravity anomaly.

Site 747 is located on the southern edge of the northern part of the plateau, whereas Sites 749 and 750 are on the northern side of the southern part of the plateau. Site 749 is approximately $100 \mathrm{~km}$ closer to the transition zone than Site 750 . One of the principal objectives of the drilling program on the Kerguelen Plateau was to determine the geochemical characteristics of the basement so as to discover its origin. A number of possible origins have been proposed for the KHP:

\footnotetext{
${ }^{1}$ Wise, S. W., Jr., Schlich, R., et al., 1992. Proc. ODP, Sci. Results, 120: College Station, TX (Ocean Drilling Program).

2 Lamont Doherty Geological Observatory of Columbia University, Palisades, NY 10562, U.S.A.

${ }^{3}$ Department of Geology, University of Leicester, United Kingdom.

4 Department of Geology and Geophysics, University of Calgary, Calgary, Alberta, Canada.

${ }^{5}$ Institut du Physique du Globe, Université Louis Pasteur, 5 rue René Descartes, Paris, France.
}

1. Continental fragment: Dietz and Holden (1970) suggested that the Kerguelen Plateau was, in part, a remnant of the Gondwana continent. Schlich et al. (1971) considered the sedimentary section of the northern plateau to have continental affinities.

2. Uplifted oceanic crust: Houtz et al. (1977) suggested that the plateau was, in part, a remnant of Cretaceous ocean basin crust that formed to the west of Australia during the separation of India from Australia-Antarctica.

3. Hotspot related: A hotspot or mantle plume origin for the KHP has been proposed by several authors on the basis of plate reconstructions and geochemistry (Duncan, 1978; Luyendyk and Rennick, 1977; Storey et al., 1989; Weis et al., 1989).

Based on seafloor magnetics from around the plateau and $\mathrm{K}-\mathrm{Ar}$ and ${ }^{40} \mathrm{Ar}{ }^{\beta 9} \mathrm{Ar}$ dates for the basement lava flows, the basement is $114 \pm 1 \mathrm{Ma}$ old (Leclaire et al., 1987; Whitechurch et al., this volume). The occurrence of beach-type deposits, combined with fossil reefs and pieces of wood just above the basement (Site 750), indicates that the KHP was above sea level during its formation approximately $114 \mathrm{Ma}$. Basement was encountered at Sites 747,749 , and 750 . Basalt was also cored at Site 748, but this basalt was encountered as a flow within the sediments and not as part of the basement. The preliminary $\mathrm{K}-\mathrm{Ar}$ age of this basalt is $80 \mathrm{Ma}$, indicating that it postdates basement formation. Hole conditions caused premature cessation of drilling operations at this site, and basement was not reached. Basement is believed to be at least $100 \mathrm{~m}$ below the intrasediment basalt flow of Site 748 .

Except for Site 748 basalts, the KHP basement basalts are aphyric to sparsely phyric hyperstene normative tholeiites, containing plagioclase and olivine as phenocrysts. Please refer to the "Petrology" sections in the site chapters of the Initial Reports of Leg 120 for a detailed description of the cored basalts. The Site 748 basalt has augite as the only phenocryst phase and no olivine. The presence of augite combined with the low $\mathrm{CaO} /$ $\mathrm{Al}_{2} \mathrm{O}_{3}$ ratio of the basalts from Site 748 indicates that this basalt already fractionated a $\mathrm{Ca}$-rich phase like augite.

In reporting the trace element and isotopic characteristics of the plateau basalts, only elements that are not susceptible to alteration processes are used. All recovered basalts are at least slightly altered, and consequently the contents of elements like $\mathrm{Ba}, \mathrm{K}, \mathrm{Rb}$, and $\mathrm{Cs}$ were changed during the 


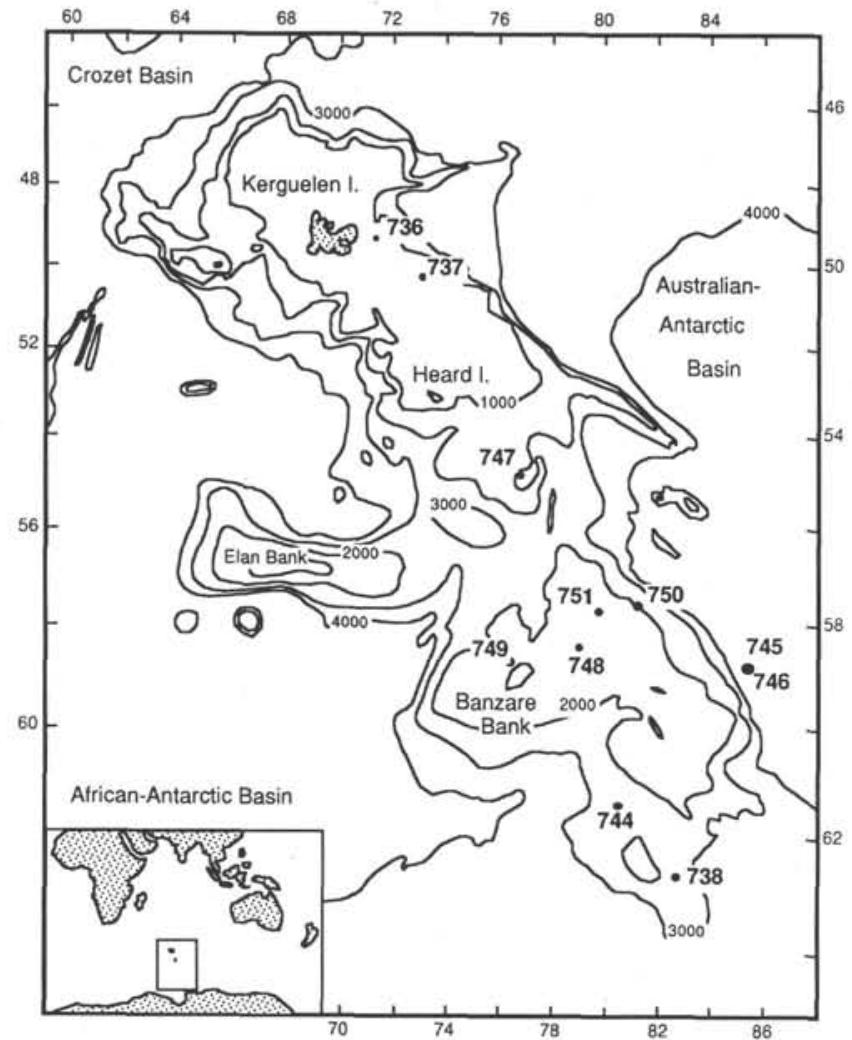

Figure 1. Map of the Kerguelen-Heard Plateau. Numbers 736 through 750 are the site numbers of Legs 119 and 120 of the Ocean Drilling Program. Sites 738 and $747-750$ recovered basalts. This study reports data for Sites 747-750. Contour interval in meters.

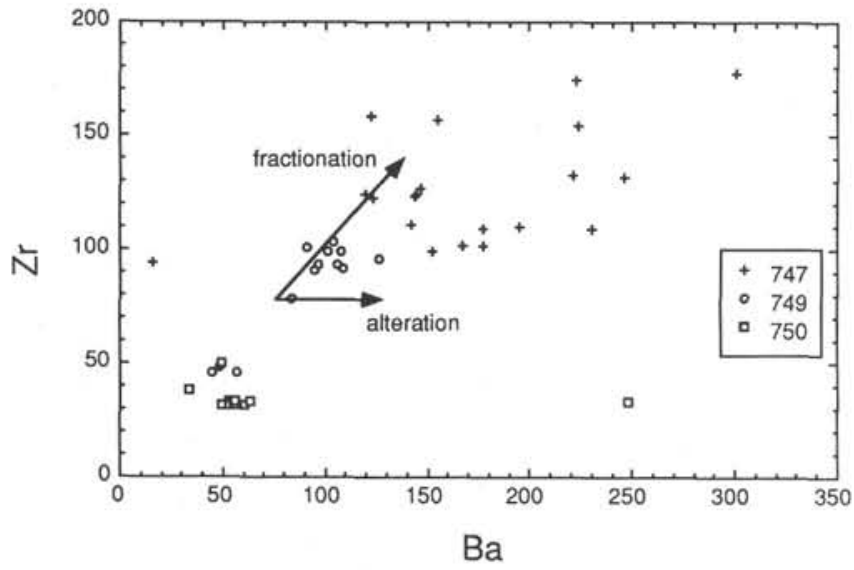

Figure 2. Diagram showing the lack of correlation between $\mathrm{Ba}$ and $\mathrm{Zr}$. $\mathrm{Ba}$ and $\mathrm{Zr}$ behave similarly during fractional crystallization and melting, and an excellent correlation is expected between these two elements. Site 747 especially shows a large range in $\mathrm{Ba}$ for a limited variation in $\mathrm{Zr}$ content, indicating $\mathrm{Ba}$ addition.

alteration process. The mobility of the alkaline and earth alkaline elements is suggested in a diagram of a mobile element (Ba) vs. an immobile element $(\mathrm{Zr})$ of similar compatibility, see Figure 2. Elements like $\mathrm{Zr}$ and $\mathrm{Ba}$ are often correlated in unaltered basaltic rocks, and variation in concentrations is mainly caused by crystal fractionation or extent of melting. Variation in $\mathrm{Ba}$ at constant $\mathrm{Zr}$ abundance is most likely caused by alteration processes. Therefore, the mobile elements during alteration should be treated with suspicion in the evaluation of the igneous variations. We will mostly use immobile trace elements to determine the petrogenesis of the KHP basalts. Elements like the rare earth elements (REE) and $\mathrm{Zr}, \mathrm{Nb}, \mathrm{Ti}, \mathrm{P}, \mathrm{Y}$, and $\mathrm{Hf}$ are not significantly affected by the alteration process. Strontium is a mobile element; therefore, ${ }^{87} \mathrm{Sr} /{ }^{86} \mathrm{Sr}$ isotope ratios reported in this paper were determined on leached samples only in the expectation that this would minimize the effects of alteration.

\section{ANALYTICAL TECHNIQUES}

Strontium was separated by standard ion exchange column chromatography, and concentrations were determined by isotope dilution using techniques described by Hart and Brooks (1977). The Nd isotope ratios and Sm-Nd concentrations were determined following the technique of Zindler (1980) as adapted from Richard et al. (1976). The $\mathrm{Pb}$ isotopic compositions were determined using the technique described by Pegram (1986) as adapted from Manhes et al (1978). The Hf isotope ratios were determined using the technique described by Salters and Hart (in press). Precision and normalization of the $\mathrm{Sr}, \mathrm{Nd}, \mathrm{Hf}$, and $\mathrm{Pb}$ isotopic data are given in Table $1 . \mathrm{Zr}$, $\mathrm{Nb}$, and $\mathrm{Y}$ were determined by $\mathrm{X}$-ray fluorescence using standard techniques. Selected basalts were analyzed for some trace elements and rare earth elements (REE) using instrumental neutron activation techniques described by Ila and Frey (1984). For $\mathrm{Sr}$ isotopic compositions samples were leached for $24 \mathrm{hr}$ in $75^{\circ} \mathrm{C} 6.2 \mathrm{~N} \mathrm{HCl}$. For most $\mathrm{Pb}$ isotopic compositions samples were also leached in $6.2 \mathrm{~N} \mathrm{HCl}$. Further leaching tests for some samples do not indicate any further decrease in ${ }^{87} \mathrm{Sr} /{ }^{86} \mathrm{Sr}$. Thus, the observed isotopic variation is thought to be real and not an artifact of alteration.

\section{RESULTS}

Results for the trace element analyses are listed in Table 1 , whereas the results of the isotopic analyses are listed in Table 2. Figure 3 shows the incompatible element patterns of basalts recovered from the four drill sites, grouped by site. The KHP basalts show a large range in $\mathrm{Ce} / \mathrm{Yb}$. Site 748 is most enriched in the light (L) REE with $\mathrm{Ce}_{\mathrm{N}} / \mathrm{Yb}_{\mathrm{N}}=40$. Site 747 is LREE enriched, although not as extreme as Site 748, with $\mathrm{Ce}_{\mathrm{N}} / \mathrm{Yb}_{\mathrm{N}}=3.5$. Site 749 shows only a slight LREE enrichment: $\mathrm{Ce}_{\mathrm{N}} / \mathrm{Yb}_{\mathrm{N}}=2$, whereas Site 750 displays flat REE patterns. Clearly, the intersite inhomogeneity is larger than the intrasite inhomogeneity. The basalts from different sites also show different degrees of enrichment in other incompatible elements like $\mathrm{Zr}, \mathrm{Nb}, \mathrm{P}, \mathrm{Y}$, Ti, etc., see Figure 4. The difference in level of trace element enrichment is independent of the $\mathrm{Mg} \#$ (= molecular $\mathrm{Mg} /[\mathrm{Mg}+\mathrm{Fe}]$ ratio) of the basalts and indicates either differences in source characteristics or differences in degree of melting for the four sites. Site 748 basalts are again extremely enriched in incompatible elements and show even higher degrees of enrichment than the alkali basalts from Heard Island. Based on some incompatible trace element ratios $(\mathrm{P} / \mathrm{Y}$ and $\mathrm{Zr} / \mathrm{Nb})$, the KHP basalts, except Site 748, are intermediate between mid-ocean ridge basalts (MORB) and oceanic-island basalts (OIB) (see Fig. 5). Diagrams like $\mathrm{P} / \mathrm{Y}$ vs. $\mathrm{Zr} / \mathrm{Nb}$ are extremely useful in discriminating between several origins of oceanic basalts. In the basalt-lherzolite system, the P/Y ratio is an indication of the enrichment/depletion of the source in moderately incompatible elements like the middle and heavy $\mathrm{REE}$; a depleted source has a low $\mathrm{P} / \mathrm{Y}$ ratio. The $\mathrm{Zr} / \mathrm{Nb}$ ratio is an indication of the enrichment in highly incompatible elements and is also more sensitive to the degree of melting, whereby enrichment or a low degree of melting leads to low 
Table 1. Trace element contents (in ppm) for Kerguelen-Heard Plateau basalts.

\begin{tabular}{|c|c|c|c|c|c|c|c|c|c|}
\hline Hole & $747 \mathrm{C}^{b}$ & $747 \mathrm{C}^{b}$ & $747 C^{b}$ & $747 C^{b}$ & $748 \mathrm{C}^{b}$ & $748 C^{a}$ & $749 C^{b}$ & $749 \mathrm{C}^{\mathrm{a}}$ & $749 C^{a}$ \\
\hline Core-section & $11 \mathrm{R}-1$ & $12 R-4$ & $16 \mathrm{R}-4$ & $16 R-5$ & $79 R-6$ & $84 \mathrm{R}-\mathrm{cc}$ & $15 R-5$ & $16 \mathrm{R}-7$ & $16 R-7$ \\
\hline Interval & $6-8$ & $36-40$ & $50-53$ & $103-106$ & $90-94$ & $0-2$ & $125-127$ & $69-74$ & $75-77$ \\
\hline La & 13.2 & 12.50 & 13.2 & 12.3 & 105 & 106 & 6.80 & 3.20 & 3.44 \\
\hline $\mathrm{Ce}$ & 32.0 & 28.6 & 28.6 & 25.5 & 224 & 297 & 18.8 & 9.6 & 8.8 \\
\hline $\mathrm{Sr}$ & 265 & 244 & 240 & 234 & 1130 & 1045 & 214 & 225 & 240 \\
\hline $\mathrm{Nd}$ & 18.0 & 17.0 & 17.0 & 15.0 & 103 & 104 & 12.3 & 6.30 & 6.7 \\
\hline $\mathrm{Zr}$ & 159 & 123 & 100 & 97 & 599 & 393 & 91 & 41 & 46 \\
\hline Hf & 3.8 & 3.30 & 2.60 & 2.20 & 19.00 & 6.20 & 2.0 & 1.10 & 1.26 \\
\hline $\mathrm{Sm}$ & 4.54 & 4.08 & 3.47 & 3.38 & 13.72 & 12.36 & 3.47 & 2.0 & 1.95 \\
\hline $\mathrm{Eu}$ & 1.37 & 1.32 & 1.14 & 0.98 & 3.61 & 3.38 & 1.22 & 0.83 & 0.89 \\
\hline $\mathrm{Ti}$ & 12208 & 9801 & 7756 & 7277 & 16476 & 18042 & 9143 & 5533 & 5293 \\
\hline $\mathrm{Tb}$ & 0.89 & 0.79 & 0.78 & 0.62 & 1.33 & 1.30 & 0.69 & 0.49 & 0.44 \\
\hline $\mathrm{Yb}$ & 2.35 & 2.83 & 2.13 & 1.91 & 1.77 & 2.20 & 2.60 & 1.39 & 1.65 \\
\hline $\mathrm{Lu}$ & 0.30 & 0.37 & 0.31 & 0.28 & 0.26 & 0.26 & 0.39 & 0.22 & 0.26 \\
\hline Hole & $749 \mathrm{Ca}^{\mathrm{a}}$ & $749 \mathrm{C}^{b}$ & $750 \mathrm{Bb}^{\mathrm{b}}$ & $750 \mathrm{~B}^{\mathrm{a}}$ & $750 \mathrm{~B}^{\mathrm{a}}$ & $750 \mathrm{~B}^{\mathrm{a}}$ & $750 \mathrm{~B}^{\mathrm{a}}$ & $750 \mathrm{~B}^{b}$ & \\
\hline Core-section & $15 R-5$ & $12 \mathrm{R}-4$ & $15 R-2$ & $17 R-3$ & $14 R-1$ & $16 R-6$ & $17 \mathrm{R}-3$ & $15 R-5$ & \\
\hline Interval & $127-131$ & $144-148$ & $88-92$ & $23-26$ & $38-40$ & $58-63$ & $26-30$ & $126-130$ & \\
\hline La & 6.30 & 6.31 & 2.50 & 4.00 & 2.71 & 2.03 & 3.15 & 1.79 & \\
\hline $\mathrm{Ce}$ & 16.6 & 17.2 & 5.60 & 8.9 & 5.50 & 2.8 & 9.30 & 6.0 & \\
\hline $\mathrm{Sr}$ & 225 & 226 & 113 & 193 & 43 & 130 & 152 & 124 & \\
\hline $\mathrm{Nd}$ & 11.0 & 10.8 & 4.50 & 6.1 & 5.0 & 3.90 & 7.30 & 3.6 & \\
\hline $\mathrm{Zr}$ & 92 & 93 & 24 & 47 & 33 & 33 & 38 & 32 & \\
\hline Hf & 2.43 & 2.43 & 0.88 & 1.20 & 0.92 & 1.01 & 1.29 & 0.86 & \\
\hline $\mathrm{Sm}$ & 3.32 & 3.52 & 1.39 & 2.22 & 1.51 & 1.41 & 2.14 & 1.33 & \\
\hline $\mathrm{Eu}$ & 1.31 & 1.32 & 0.60 & 0.84 & 0.54 & 0.65 & 0.93 & 0.63 & \\
\hline $\mathrm{Ti}$ & 8358 & 8419 & 4268 & 7037 & 5232 & 4329 & 5232 & 4090 & \\
\hline $\mathrm{Tb}$ & 0.70 & 0.77 & 0.40 & 0.58 & 0.53 & 0.42 & 0.59 & 0.40 & \\
\hline $\mathrm{Yb}$ & 2.65 & 2.90 & 2.06 & 2.57 & 1.88 & 2.22 & 2.39 & 1.94 & \\
\hline $\mathrm{Lu}$ & 0.40 & 0.40 & 0.29 & 0.34 & 0.32 & 0.33 & 0.43 & 0.31 & \\
\hline
\end{tabular}

Notes: $\mathrm{Ti}$ and $\mathrm{Zr}$ are shipboard XRF data; all other elements are INAA.

aSamples were analyzed at MIT.

${ }^{b}$ Samples were analyzed at Leicester.

Table 2. Sr, Nd, and Pb isotopic compositions of the Kerguelen-Heard Plateau basalts collected on Leg 120.

\begin{tabular}{|c|c|c|c|c|c|c|c|c|}
\hline Site & Core & Interval & ${ }^{87} \mathrm{Sr} / 86 \mathrm{Sr}$ & $143 \mathrm{Nd} /{ }^{144} \mathrm{Nd}$ & $176 \mathrm{Hf} / 177 \mathrm{Hf}$ & $206 \mathrm{~Pb} / 204 \mathrm{~Pb}$ & $207 \mathrm{~Pb} / 204 \mathrm{~Pb}$ & $208 \mathrm{~Pb} / 204 \mathrm{~Pb}$ \\
\hline $747 \mathrm{C}$ & $12 R-4$ & $45-46$ & 0.705508 & 0.512435 & 0.282722 & 17.466 & 15.461 & 37.977 \\
\hline $747 \mathrm{C}$ & $16 \mathrm{R}-2$ & $85-87$ & 0.705895 & 0.512452 & 0.282600 & 18.275 & 15.643 & 38.459 \\
\hline $747 \mathrm{C}$ & $12 \mathrm{R}-2$ & $122-124$ & 0.705660 & 0.512445 & - & - & - & - \\
\hline $747 \mathrm{C}$ & $16 \mathrm{R}-2$ & $81-84$ & 0.705866 & 0.512410 & - & 17.608 & 15.508 & 38.072 \\
\hline $748 \mathrm{C}$ & $79 R-7$ & $65-67$ & 0.705157 & 0.512491 & 0.282659 & 18.305 & 15.613 & 38.495 \\
\hline $749 \mathrm{C}$ & $16 \mathrm{R}-7$ & $107-109$ & 0.703506 & - & - & 18.031 & 15.579 & 38.222 \\
\hline $749 \mathrm{C}$ & $15 \mathrm{R}-2$ & $35-37$ & 0.704237 & 0.512763 & - & 18.200 & 15.625 & 38.435 \\
\hline $749 \mathrm{C}$ & $12 R-4$ & $144-148$ & 0.704268 & - & 0.282883 & 17.980 & 15.587 & 38.204 \\
\hline $749 \mathrm{C}$ & $15 \mathrm{R}-5$ & $127-130$ & 0.704306 & 0.512764 & 0.283009 & 17.978 & 15.587 & 38.213 \\
\hline $749 \mathrm{C}$ & $16 R-7$ & $75-77$ & 0.703531 & - & - & 18.065 & 15.574 & 38.028 \\
\hline $750 \mathrm{~B}$ & $16 \mathrm{R}-3$ & $134-136$ & 0.705012 & 0.512902 & - & 18.112 & 15.585 & 38.405 \\
\hline $750 \mathrm{~B}$ & $17 R-3$ & $26-30$ & 0.705300 & - & - & - & - & - \\
\hline
\end{tabular}

Notes: ${ }^{87} \mathrm{Sr} /{ }^{86} \mathrm{Sr}$ is relative to 0.70800 for E\&A standard; ${ }^{143} \mathrm{Nd} / 144 \mathrm{Nd}$ is relative to 0.51262 for $\mathrm{BCR}-1$ standard; and ${ }^{143} \mathrm{Nd} /{ }^{144} \mathrm{Nd}$ is normalized to ${ }^{146} \mathrm{Nd} /{ }^{144} \mathrm{Nd}$ $=0.7219$. ${ }^{176} \mathrm{Hf} /{ }^{177} \mathrm{Hf}$ is relative to 0.282200 for JMC $475 .{ }^{176} \mathrm{Hf} /{ }^{177} \mathrm{Hf}$ is normalized to ${ }^{177} \mathrm{Hf} /{ }^{178} \mathrm{Hf}=0.6816 . \mathrm{Pb}$ isotopes have been normalized to the NBS 981 standard; the precision is better than $0.05 \%$ per amu.

$\mathrm{Zr} / \mathrm{Nb}$ ratios. The southernmost basalts are more MORBlike whereas the northernmost basalts resemble Kerguelen and Heard island volcanics, although none of the plateau basalts have trace element characteristics as depleted as MORB. Except for Site 748 basalts the KHP basalts have $\mathrm{P} / \mathrm{Y}$ ratios similar to MORB, but $\mathrm{Zr} / \mathrm{Nb}$ ratios are significantly lower than MORB.
Variations in $\mathrm{Sr}$ and $\mathrm{Nd}$ isotopic compositions of the KHP basalts cover a large part of the range of oceanic volcanics. None of the samples are age corrected. Using the trace element concentrations of the leached basalts the age correction is small for $\mathrm{Nd}$. An age correction for ${ }^{87} \mathrm{Sr} /{ }^{86} \mathrm{Sr}$ is difficult because the $\mathrm{Rb}$ concentrations are affected by the alteration process. An $\mathrm{Rb} / \mathrm{Sr}$ ratio can be estimated by comparing the incompatible trace 

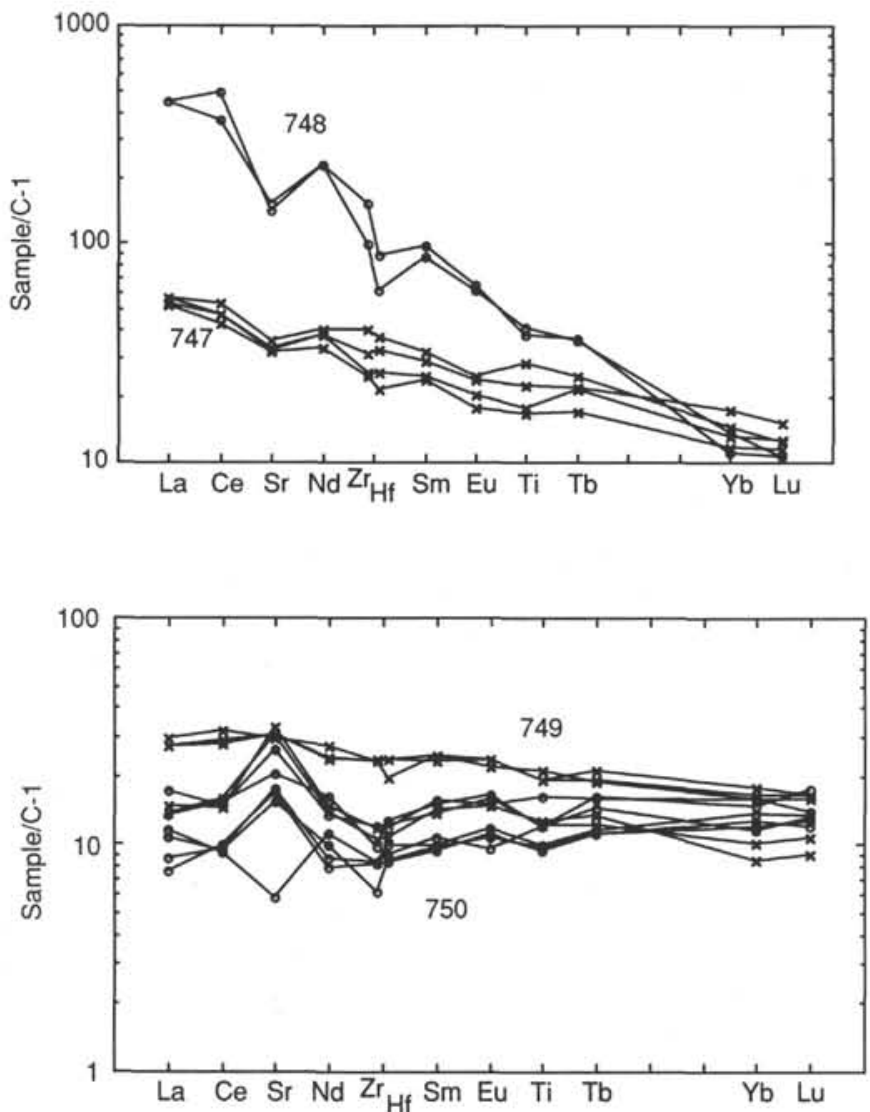

Figure 3. Spider diagrams for KHP basalts. LREE enrichment decreases from Sites 747 to 749 and 750 . Normalization values used are C-1 values from Anders and Grevesse (1989).

element pattern of the KHP basalts with similar trace element pattern of fresh oceanic volcanics. The $\mathrm{Rb} / \mathrm{Sr}$ ratio of these comparable basalts is taken as the $\mathrm{Rb} / \mathrm{Sr}$ ratio of the KHP basalts. This age correction can be up to 0.0001 for ${ }^{87} \mathrm{Sr} /{ }^{\beta 6} \mathrm{Sr}$ (Site 748) basalts, which is insignificant compared with the total variation of the KHP basalts, and will not significantly affect the nature of the variations observed and discussed in the KHP basalts. The total range for ${ }^{87} \mathrm{Sr} /{ }^{86} \mathrm{Sr}$ from 0.7035 to 0.7059 and for ${ }^{143} \mathrm{Nd} /{ }^{144} \mathrm{Nd}$ from 0.51291 to 0.51241 is larger than the variation of any other oceanic-island chain or oceanic plateau. The four different sites occupy different areas on the $\mathrm{Nd}-\mathrm{Sr}$ isotope correlation diagram. The trace elements support the isotope ratios in that the samples that are most depleted in LREE also have more depleted Nd isotopic signatures (see Fig. 6). However, the ${ }^{87} \mathrm{Sr} /{ }^{86} \mathrm{Sr}$ of Site 749 basalts is lower than the ${ }^{87} \mathrm{Sr} /{ }^{86} \mathrm{Sr}$ for the more LREE depleted Site 750 basalts. The large variation in isotopic composition of the basement of the plateau indicates the existence of significant heterogeneities in the mantle underneath the plateau. The plateau data overlap for a large part with the field for Kerguelen Island volcanics (Fig. 7). The northern site and the alkali basalt (Site 748) overlap with the most enriched end of the Kerguelen Island field, though they are separate from the Heard Island field. A limited number of samples have been analyzed for Hf isotopic composition. On a $\mathrm{Hf}-\mathrm{Nd}$ isotope correlation diagram ${ }^{143} \mathrm{Nd} /{ }^{144} \mathrm{Nd}$ and ${ }^{176} \mathrm{Hf} /{ }^{177} \mathrm{Hf}$ are correlated and fall within the range of other ocean-island volcanics, see Figure 8.

The $\mathrm{Pb}$ isotope ratios for the KHP basalts vary from 17.47 to 18.31 for ${ }^{206} \mathrm{~Pb} /{ }^{04} \mathrm{~Pb}$, from 15.46 to 15.62 for ${ }^{207} \mathrm{~Pb} /{ }^{204} \mathrm{~Pb}$, and
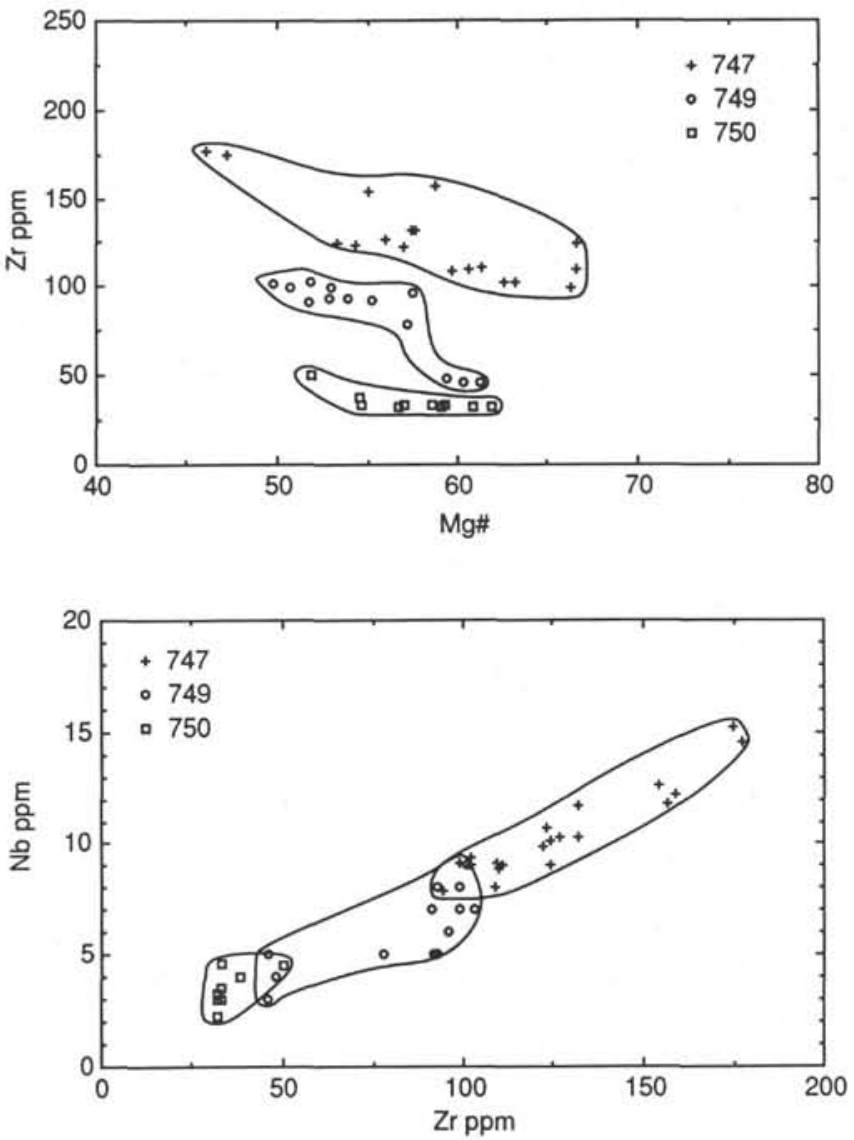

Figure $4 . \mathrm{Zr}$ vs. $\mathrm{Mg}$ \# and $\mathrm{Nb}$ for KHP basalts. Site 748 basalts are so enriched that they plot off scale. Different sites have different $\mathrm{Zr}$ content for given $\mathrm{Mg}$ \#. The plot of $\mathrm{Zr}$ vs. $\mathrm{Nb}$ indicates that the difference in trace element characteristics is a difference in degree of enrichment. Incompatible elements do seem to be correlated from site to site, indicating that they could represent different degrees of melting from a similar source. The isotopic composition, however, indicates different source materials for the different sites.

from 37.9 to 38.5 for ${ }^{208} \mathrm{~Pb} / 204 \mathrm{~Pb}$. The KHP basalts fall above the Northern Hemisphere Reference Line as defined by Hart (1984), indicating contribution from a component with a high $\mathrm{U} / \mathrm{Pb}$ early in the Earth's history. The $\mathrm{Pb}$ isotope values overlap with the field for the Walvis Ridge basalts. Figure 9 illustrates the $\mathrm{Sr}-\mathrm{Pb}$ isotopic variations for the KHP basalts, where again the KHP basalts overlap with Kerguelen Island and Walvis Ridge basalts.

\section{DISCUSSION}

The KHP basalts show extreme variations in their Nd and $\mathrm{Sr}$ isotopic composition. However, the KHP basalts lie within the field of oceanic-island basalts, outside the MORB field, indicating the absence of continental crust beneath the Kerguelen-Heard Plateau. The lack of incompatible element enrichment in basalts from Sites 749 and 750 also argues against the presence of continental crust. And, third, the lack of any other type of basement than basaltic also indicates an oceanic origin for the KHP. Dredge basalts from the KHP also display large variations in their $\mathrm{Sr}, \mathrm{Nd}$, and $\mathrm{Pb}$ isotopic composition (Weis et al., 1989). The variations of the dredge basalts are within the range reported here. The large variation in isotopic 


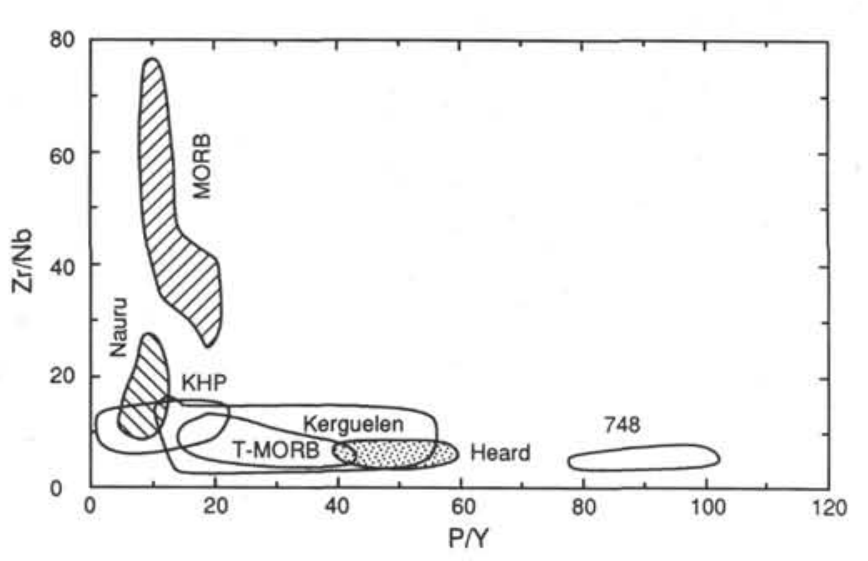

Figure 5. $\mathrm{P} / \mathrm{Y}$ vs. $\mathrm{Zr} / \mathrm{Nb}$ showing the interelement variation for basalts from all Leg 120 sites with respect to MORB (Price et al., 1986), transitional MORB (le Roex et al., 1987), and plateau basalts from the Nauru Basin (Saunders, 1985) and Kerguelen and Heard islands (Storey, unpubl. data).

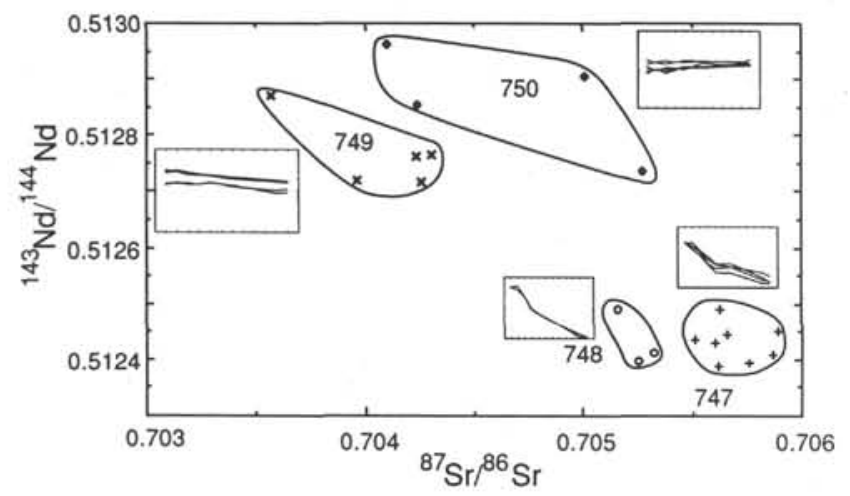

Figure 6. Sr-Nd isotope correlation diagram for the Kerguelen Plateau basalts. The four sites occupy different areas on the diagram, indicating different source characteristics for the sites. Insets are the REE patterns for the lavas. Vertical axis for the REE diagrams is from 1 to 100 for Sites 749 and 750 , from 10 to 100 for Site 747 , and from 10 to 1000 for Site 748. Data from this study and Storey et al. (1990).

composition of the basement of the plateau indicates the existence of significant heterogeneities in the mantle under the plateau. Any model for the formation of the plateau has to explain these large isotopic variations. Mutter et al. (1988) proposed that plateaus might reflect excess volcanism resulting from local vigorous convection. We expect that vigorous convection led to increased mixing and a homogeneous character of the volcanic products. However, the opposite is observed for the KHP, and the range in isotopic composition of the KHP basement is larger than the range in isotopic composition of a ridge segment or island chain of similar geographic dimensions. The large variations of the KHP basement argue against the possibility of increased convection as an origin for plateau formation.

Salters and Hart (1989) showed how the combined Hf and $\mathrm{Nd}$ isotope systematics can give an indication of the degree of melting, and depth of the onset of melting of basalts. They used the isotope ratios of the basalts to calculate a parent/ daughter ratio of the basalt source. In their model the difference between the calculated parent/daughter ratio in the source and the measured ratio in the basalts was

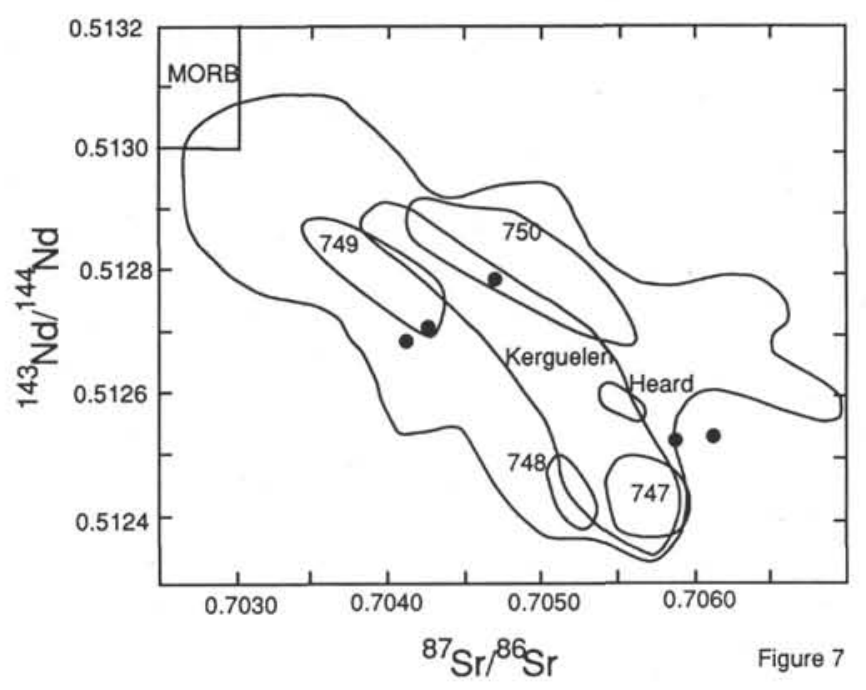

Figure $7 .{ }^{87} \mathrm{Sr} /{ }^{86} \mathrm{Sr}$ vs. ${ }^{143} \mathrm{Nd} /{ }^{144} \mathrm{Nd}$, and for the KHP basalts compared with OIB. The high ${ }^{87} \mathrm{Sr} /{ }^{86} \mathrm{Sr}$ KHP basalts overlap with the high ${ }^{87} \mathrm{Sr} /{ }^{86} \mathrm{Sr}$ basalts from Kerguelen Island. None of the Plateau basalts overlap with Heard Island basalts. Field for Heard Island from Storey et al. (1989), fields for other OIB and MORB from Zindler and Hart (1986). The high ${ }^{87} \mathrm{Sr} /{ }^{86} \mathrm{Sr}$ basalts of the KHP are clearly part of the EMI end-member. Solid circles are dredge samples from the KHP reported by Weis et al. (1989).

attributed to the melting process. They found that, to explain the combined trace element and isotopic characteristics of MORB and OIB, the onset of melting has to be placed in the garnet stability field (see Salters and Hart, 1989, for details). Furthermore, estimates for the degree of melting to generate the combined trace element and isotopic characteristics were also calculated with this model. Using this approach the estimate of the range of degree of melting for the KHP basalts is similar or less than the estimated range for MORB. Although the absolute value of those estimates for the degree of melting is dependent on the age of the basalt source and the specifics of the melt model, the relative difference in the degree of melting between individual basalts is a robust number. These estimates are a second indication that the plateau is not formed by a process involving degrees of melting in excess of those for MORB.

The geochemical diversity of Indian Ocean Ridge basalts has been well documented (Dosso et al., 1988; Dupré and Allègre, 1983; Frey et al., 1980; Hamelin et al., 1986; Ito et al., 1987; le Roex et al., 1985; Price et al., 1986). In general, the Indian Ocean Ridge basalts distinguish themselves from Pacific or Atlantic Ocean ridge basalts by their higher ${ }^{207} \mathrm{~Pb} /{ }^{04} \mathrm{~Pb}$ for given ${ }^{206} \mathrm{~Pb} /$ ${ }^{204} \mathrm{~Pb}$ and lower ${ }^{143} \mathrm{Nd} / 144 \mathrm{Nd}$ and higher ${ }^{87} \mathrm{Sr} /{ }^{86} \mathrm{Sr}$. These isotopic characteristics can be largely explained as mixing between a depleted MORB-type end-member mantle (DMM) and an enriched mantle component (EMI) in the terminology of Zindler and Hart (1986). Dosso et al. (1988) argue on the basis of the high ${ }^{206} \mathrm{~Pb} / 204 \mathrm{~Pb}$ and ${ }^{208} \mathrm{~Pb} /{ }^{204} \mathrm{~Pb}$ ratios of some of the southeast Indian ridge basalts that a third component is present beneath the Indian Ocean. This third component could have isotopic characteristics similar to the EMII-enriched mantle end-member as defined by Zindler and Hart (1986).

The $\mathrm{Sr}$ and Nd isotopic characteristics of Kerguelen Island can be explained by mixing between a depleted end-member with high ${ }^{143} \mathrm{Nd} /{ }^{144} \mathrm{Nd}$ and low ${ }^{87} \mathrm{Sr} /{ }^{86} \mathrm{Sr}(\mathrm{DMM})$ and an enriched end-member (EMI). The $\mathrm{Pb}$ isotopic composition of Kerguelen Island volcanics is restricted (Gautier et al., 1989) and indicates 


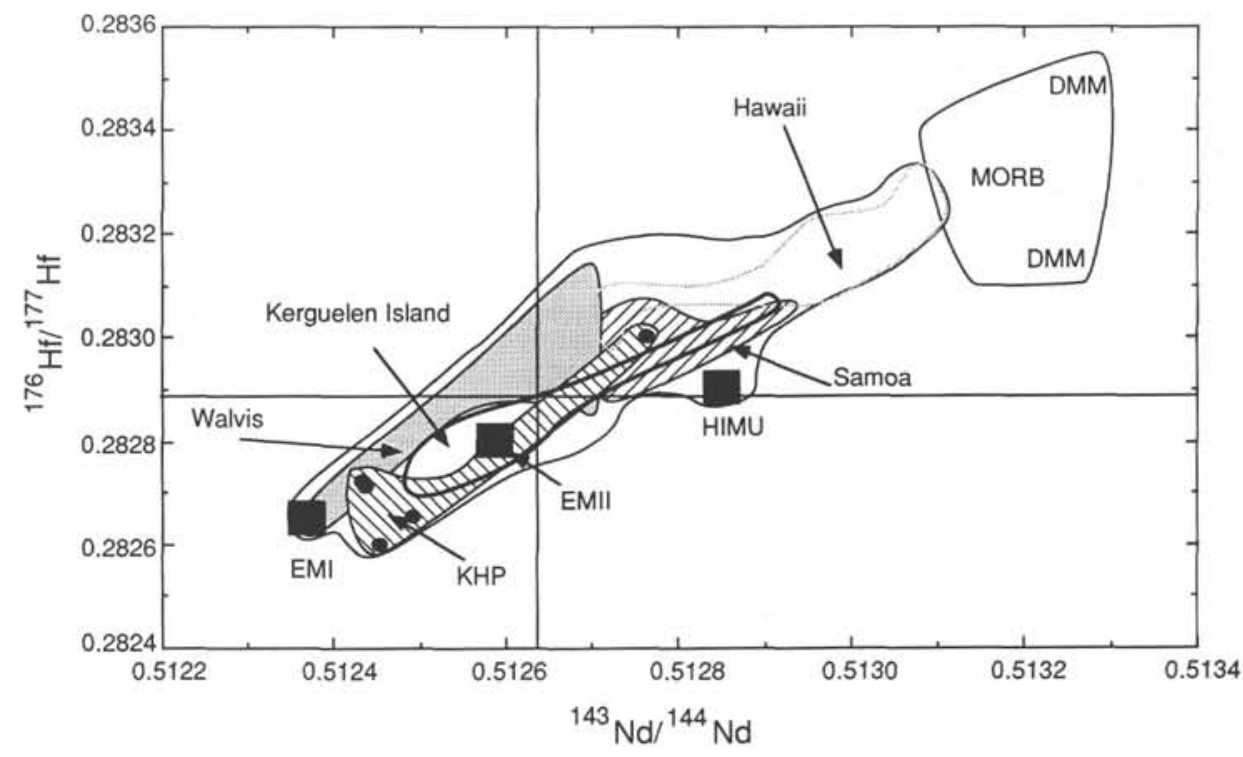

Figure 8. Hf-Nd isotope correlation diagrams of volcanics. OIB data from Hart et al. (1986), Patchett (1983), Patchett and Tatsumoto (1981), W. M. White (unpubl. data), and Salters (1989). Mantle end-members are indicated as blocks. The definition and location of the mantle end-members is according to Salters and Hart (in press). Solid circles are data for the Leg 120 basalts. Straight lines indicate the location of bulk earth.

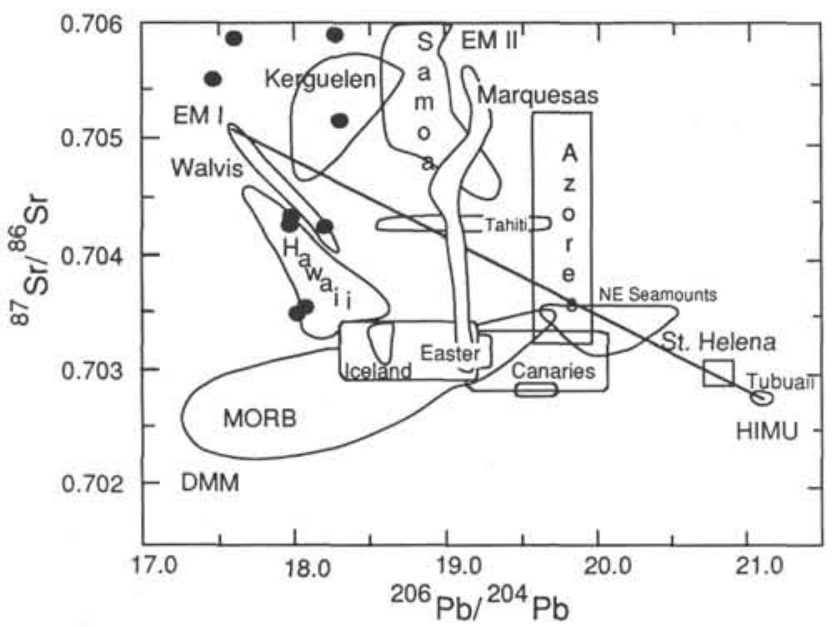

Figure 9. ${ }^{206} \mathrm{~Pb} / 204 \mathrm{~Pb}$ vs. ${ }^{87} \mathrm{Sr} /{ }^{86} \mathrm{Sr}$. for $\mathrm{KHP}$ basalts and assorted oceanic volcanics. Solid circles are analyses from both this study and Weis et al. (1989). The range in ${ }^{206} \mathrm{~Pb} / 204 \mathrm{~Pb}$ for the plateau volcanics is larger than for the island volcanics. Ocean-island fields are from Zindler and Hart (1986).

that the island volcanics contain a third component that falls above the Northern Hemisphere Reference Line (Hart, 1984), but with a ${ }^{206} \mathrm{~Pb} / 204 \mathrm{~Pb}$ of 18.5 or higher. Heard Island volcanics display $\mathrm{Sr}-\mathrm{Nd}$ and $\mathrm{Pb}$ characteristics similar to Kerguelen Island (Barling et al., 1988; Storey et al., 1988). The high ${ }^{207} \mathrm{~Pb} /{ }^{04} \mathrm{~Pb}$ for a given ${ }^{206} \mathrm{~Pb} / 204 \mathrm{~Pb}$, the high ${ }^{206} \mathrm{~Pb} /{ }^{204} \mathrm{~Pb}$ and the enriched $\mathrm{Sr}$ - and Nd-isotopic characteristics of the basalts are typical for Indian Ocean basalts, and numerous authors refer to this as the DUPAL component in the Indian Ocean basalts (Price et al., 1986; Storey et al., 1989; Storey et al., 1988; Weis et al., 1989) in analogy of the DUPAL anomaly as defined by Hart (1984). However, both EMI and EMII have some DUPAL characteristics, and we therefore prefer to refer to the individual mantle components instead of end-member mixtures. The KHP basalts are a clear example of the presence of both EMI and EMII. The low ${ }^{87} \mathrm{Sr} /{ }^{86} \mathrm{Sr}$ end of the field of the KHP basalts on ${ }^{206} \mathrm{~Pb} /{ }^{204} \mathrm{~Pb}$ ${ }^{87} \mathrm{Sr} /{ }^{86} \mathrm{Sr}$ diagram is at higher ${ }^{206} \mathrm{~Pb} / 204 \mathrm{~Pb}$ than $\mathrm{DMM}$, indicating that even in the most MORB-like basalts EMII is already present, see Figure 9.

Site 747 and the alkali basalt (Site 748) overlap with the most enriched end of the Kerguelen Island field, though they separate from the Heard Island field, see Figure 7. Also, the trace element characteristics of Site 747 and 748 are similar to those of Kerguelen and Heard Island, Storey et al. (1990). The KHP basalts are lower in ${ }^{143} \mathrm{Nd} /{ }^{144} \mathrm{Nd}$ and higher in ${ }^{87} \mathrm{Sr} /{ }^{86} \mathrm{Sr}$ than other oceanic-plateau volcanics (Cheng et al., 1987; Mahoney, 1987). Furthermore, it can be seen from Figure 7 that the Site 747 and 748 basalts lie towards the Enriched Mantle I (EMI) component as defined by (Zindler and Hart (1986). In $\mathrm{Sr}-\mathrm{Pb}$ isotopic composition space, the KHP basalts again overlap with the field of the Kerguelen Island basalts, and are proximal to the EMI end-member. Previously the EMI mantle component was defined by the most enriched end of the Walvis Ridge array. The KHP basalts now also define the location of the EMI endmember. Only a small number of oceanic volcanics are analyzed for $\mathrm{Hf}$ and $\mathrm{Nd}$ isotopic composition. However, the correlation between $\mathrm{Hf}$ and $\mathrm{Nd}$ isotopes in oceanic-island volcanics is extremely good. The KHP basalts fit these general characteristics, and also in Nd-Hf space the KHP basalts overlap with Kerguelen Island and Walvis Ridge basalts and thereby determine the EMI end-member in $\mathrm{Sr}-\mathrm{Nd}-\mathrm{Hf}-\mathrm{Pb}-\mathrm{Pb}-\mathrm{Pb}$ isotopic hyperspace (Fig. 8). The EMII end-member is internal to the Hf-Nd isotopic array formed by oceanic-island volcanics. Thus, the Hf-Nd isotope space is not suited for determining the contribution of EMII to the KHP basalts.

It is proposed that the KHP is formed in a situation analogous to present-day Iceland: a ridge centered hot spot (Munschy and Schlich, 1988; Mutter and Cande, 1983). The geochemical data presented here are in agreement with this hypothesis. Especially the characteristics of Site 750 and 749 basalts: low LREE/HREE ratios, low in other incompatible element contents, and depleted $\mathrm{Nd}, \mathrm{Hf}$, and $\mathrm{Sr}$ isotopic characteristics, indicate the presence of 
depleted, MORB-type, mantle beneath the KHP. However, the pure depleted mantle end-member (DMM) in Zindler and Hart (1986) terminology is not present in any of the plateau volcanics. The two principal end-members beneath the KHP are DMM and EMI, whereby Site 749 and 750 have a larger DMM component than the two other sites. The dominance of the EMI component in the KHP and Kerguelen Island volcanics has also been noticed by Weis et al. (1989).

The volcanism leading to the formation of the KHP ceased $100 \mathrm{Ma}$ ago. On Kerguelen Island, the oldest lavas are $=45 \mathrm{Ma}$ in age and are of transitional MORB to OIB type (Gautier et al., 1989; Storey et al., 1988). The later stage Kerguelen Island and the Heard Island basalts are more enriched in incompatible trace element content than the 45-Ma Kerguelen Island basalts. Except for the occurrence of the basalt flow at Site 748, no volcanic activity was found between \pm 110 and $45 \mathrm{Ma}$. The fact that the plateau- and island-forming stages of volcanism, which are at least $60 \mathrm{Ma}$ apart, share the same mantle component suggests that this mantle component is continuously present below the plateau. The EMI component is associated with both the "plateau-forming phase" and the hotspot stage of the plateau. The sampling at Kerguelen Island (the hotspot stage) of the EMI reservoir might simply be the retapping of the EMI-DMM mantle mix that was placed at low levels in the mantle during the plateau-forming stage. However, most important is the simultaneous occurrence of the EMI and DMM end-member, indicating a long-term spatial association of these two mantle components. Richardson et al. (1983) proposed a similar mixing relationship for the Walvis Ridge samples. The Walvis Ridge array is proposed to be formed by mixing of an enriched mantle (later defined as EMI; Zindler and Hart, 1986), and a depleted MORBtype end-member, also indicating a spatial relationship between EMI and DMM.

\section{CONCLUSIONS}

The Kerguelen Plateau basement rocks consist of basalts that have trace element and isotopic characteristics very similar to other oceanic basalts. These geochemical characteristics of the basement of the Kerguelen Plateau combined with the absence of evolved rocks (i.e., granites, granodiorites, or dacites) indicate a completely oceanic origin for the plateau. Site 747 basalts together with the Walvis Ridge basalts are extreme in isotopic composition, and they define the enriched mantle I (EMI) end-member.

The estimated degree of melting for the KHP basalts is similar or less than required for MORB genesis. This combined with the heterogeneous isotopic character of the basement excludes models that call for an increased degree of mixing or melting to explain the excess height of the plateau over "normal" seafloor of similar age.

The plateau basalts and the island-forming volcanics are similar in isotopic composition, indicating the presence of a similar mantle beneath the plateau during the entire $114 \mathrm{Ma}$ of its existence. The mantle beneath the plateau is mainly a mixture of DMM and EMI, but it has characteristics that indicate the involvement of EMII.

\section{REFERENCES}

Anders, E., and Grevesse, N., 1989. Abundances of the elements: meteoritic and solar. Geochim. Cosmochim. Acta, 53:197-214.

Barling, J., Goldstein, S. L., Wheller, G. E., and Nicholls, I. A., 1988. Heard Island: an example of large isotopic variations on a small oceanic island. Chem Geol., 70:46.

Cheng, Q., Park, K.-H., Macdougall, J. D., Lugmair, G. W., Hawkins, J., and Lonsdale, P., 1988. Isotopic evidence for a hotspot origin of the Louisville seamount chain. In Keating, B. H., Fryer,
P., Batiza, R., and Boehlert, G. W. (Eds.), Seamounts, Islands, and Atolls. Am. Geophys. Union Monogr., 43:283-296.

Dietz, R. S., and Holden, J. C., 1970. Reconstruction of Pangaea: breakup and dispersion of continents, Permian to Present. $J$. Geophys. Res., 75:4939-4956.

Dosso, L., Bougault, H., Beuzart, P., Calvez, J. Y., and Joron, J. L., 1988. The geochemical structure of the Southeast Indian Ridge. Earth Planet. Sci. Lett., 88:47-59.

Duncan, R. A., 1978. Geochronology of basalts from the Ninetyeast Ridge and continental dispersion in the eastern Indian Ocean. $J$. Volcanol. Geotherm. Res., 4:283-305.

Dupré, B., and Allègre, C. J., 1983. Pb-Sr isotope variation in Indian Ocean and mixing phenomena. Nature, 303:142-146.

Frey, F. A., Dickey, J. S., Thompson, G., Bryan, W. B., and Davies, H. L., 1980. Evidence for heterogeneous primary MORB and mantle sources, NW Indian Ocean. Contrib. Mineral. Petrol. 74:387-402.

Gautier, I., Giret, A., Vidal, P., Di Donato, G., and Weis, D., 1990. Petrology and geochemistry of Kerguelen basalts (south Indian Ocean): evolution of a hotspot from a ridge to an intraplate position. Earth Planet. Sci. Lett., 100:59-76.

Hamelin, B., Dupré, B., and Allègre, C. J. 1986. Pb-Sr-Nd isotopic data of Indian Ocean ridges: new evidence of large-scale mapping of mantle heterogeneities. Earth Planet. Sci. Lett., 76:288-298.

Hart, S. R., 1984. The DUPAL anomaly: a large-scale isotopic mantle anomaly in the Southern Hemisphere. Nature, 309:753-757.

Hart, S. R., and Brooks, C., 1977. The geochemistry and evolution of the early Precambrian mantle. Contrib. Mineral. Petrol., 61:109-128.

Hart, S. R., Gerlach, D. C., and White, W. M., 1986. A possible new $\mathrm{Sr}-\mathrm{Nd}-\mathrm{Pb}$ mantle array and consequences for mantle mixing. Geochim. Cosmochim. Acta, 50:1551-1557.

Houtz, R. E., Hayes, D. E., and Markl, R. G., 1977. Kerguelen Plateau bathymetry, sediment distribution and crustal structure. Mar. Geol., 25:95-130.

Ila, P., and Frey, F. A., 1984. Utilization of neutron activation analysis in the study of geological materials. Atomkernenerg./ Kerntech., 44:710-716.

Ito, E., White, W. M., and Goepel, C., 1987. The O, Sr, Nd, and Pb isotope geochemistry of MORB. Chem. Geol., 62:157-176.

Leclaire, L., Bassias, Y., Denis-Clocchiatti, M., Davies, H., Gautier, I., and Wannesson, J., 1987. Lower Cretaceous basalt and sediment from the Kerguelen Plateau. Geo-Mar. Lett., 7:169-176.

le Roex, A. P., Dick, H.J.B., Gulen, L., Reid, A. M., and Erlank, A. J., 1987. Local and regional heterogeneity in MORB from the midAtlantic ridge between $54.5^{\circ} \mathrm{S}$ and $51^{\circ} \mathrm{S}$ : evidence for geochemical enrichment. Geochim. Cosmochim. Acta, 51:541-556.

le Roex, A. P., Dick, H.J.B., Reid, A. M., Frey, F. A., Erlank, A. J., and Hart, S. R., 1985. Petrology and geochemistry of basalts from the American-Antarctic Ridge, Southern Indian Ocean: implications for the westward influence of the Bouvet mantle plume. Contrib. Mineral. Petrol., 90:367-380.

Luyendyk, B. P., and Rennick, W., 1977. Tectonic history of aseismic ridges in the eastern Indian Ocean. Geol. Soc. Am. Bull., 88:1347-1356.

Mahoney, J. J., 1987. An isotopic study of Pacific oceanic plateaus: implications for their nature and origin. In Keating, B. H., Fryer, P., Batiza, R., and Boehlert, G. W. (Eds.), Seamounts, Islands, and Atolls. Am. Geophys. Union Monogr., 43:207-220.

Manhes, G., Minster, J., and Allègre, C. J., 1978. Comparative uranium-thorium-lead and rubidium-strontium of St. Severin amphoterite: consequences for early solar system chronology. Earth Planet. Sci. Lett., 39:14-24.

Munschy, M., and Schlich, R., 1988. Structure and evolution of the Kerguelen-Heard Plateau (Indian Ocean) deduced from seismic stratigraphy studies. Mar. Geol., 76:131-152.

Mutter, J. C., Buck, W. R., and Zehnder, C. M., 1988. Convective partial melting. I. A model for the formation of thick basaltic sequences during initiation of spreading. J. Geophys. Res., 93:1031-1048.

Mutter, J. C., and Cande, S. C., 1983. The early opening between Broken Ridge and Kerguelen Plateau. Earth Planet. Sci. Lett., 65:369-376.

Patchett, P. J., 1983. Importance of the Lu-Hf isotopic system in studies of planetary chronology and chemical evolution. Geochim. Cosmochim. Acta, 47:81-91. 
Patchett, P. J., and Tatsumoto, M., 1981. Lu/Hf in chondrites and definition of a chondritic hafnium growth curve. Lunar Planet. Sci., No. 12.

Pegram, W. J., 1986. Geochemical processes in the sub-continental mantle and the nature of crust mantle interaction: evidence from the Mesozoic Appalachian Tholeiite Province [Ph.D. dissert]. Mass. Inst. Tech., Cambridge.

Price, R. C., Kennedy, A. K., Riggs-Sneeringer, M., and Frey, F. A., 1986. Geochemistry of basalts from the Indian Ocean triple junction: implication for the generation and evolution of Indian Ocean ridge basalts. Earth Planet. Sci. Lett., 78:279-296.

Richard, P. N., Shimizu, N., and Allègre, C. J., 1976. ${ }^{143} \mathrm{Nd} /{ }^{144} \mathrm{Nd}$, a natural tracer: an application to oceanic basalts. Earth Planet. Sci. Lett., 31:269-278.

Salters, V.J.M., 1989. The use of Hf isotopes and high-field-strength elements to constrain magmatic processes and magma sources [Ph.D. dissert.]. Mass. Inst. Tech., Cambridge.

Salters, V.J.M., and Hart, S. R., 1989. The hafnium paradox and the role of garnet in the source of mid-ocean-ridge basalts. Nature, $342: 420-422$.

in press. The mantle sources of ocean islands and arc basalts: the Hf isotope connection. Earth Planet. Sci. Lett.

Saunders, A. D., 1985. Geochemistry of basalts from the Nauru Basin, Deep Sea Drilling Project Legs 61 and 89: implications for the origin of oceanic flood basalts. In Moberly, R., Schlanger, S. O., et al., Init. Repts. DSDP, 89: Washington (U.S. Govt. Printing Office), 499-517.

Schlich, R., 1975. Structure et âge de l'Océan Indien Occidental. Mem. Hors-Ser. Soc. Geol. Fr., 6:1-103.
Schlich, R., Delteil, J. R., Moulin, J., Patriat, P., and Guillaume, R., 1971. Mise en évidence d'un sédimentation de marge continentale sur le plateau de Kerguelen-Heard. C. R. Acad. Sci. Paris, 272:2060-2063.

Storey, M., Saunders, A. D., Tarney, J., Gibson, I. L., Norry, M. J., Thirwall, M. F., Leat, P., Thompson, R. N., and Menzies, M. A., 1989. Contamination of Indian Ocean asthenosphere by the Kerguelen-Heard mantle plume. Nature, 338:574-576.

Storey, M., Saunders, A. D., Tarney, J., Leat, P., Thirwall, M. F., Thompson, R. N., Menzies, M. A., and Marriner, G. F., 1988. Geochemical evidence for plume-mantle interactions beneath Kerguelen and Heard islands, Indian Ocean. Nature, 336:371-374.

Weis, D., Bassias, Y., Gautier, I., and Mennessier, J., 1989. Dupal anomaly in existence $115 \mathrm{Ma}$ ago: evidence from isotopic study of the Kerguelen Plateau (South Indian Ocean). Geochim. Cosmochim. Acta, 53:2125-2131.

Zindler, A., 1980. Geochemical processes in the Earth's mantle and the nature of crust-mantle interactions: evidence from studies of $\mathrm{Nd}$ and $\mathrm{Sr}$ isotope ratios in mantle-derived igneous rocks and lherzolite nodules [Ph.D. dissert.]. Mass. Inst. Tech., Cambridge.

Zindler, A., and Hart, S. R., 1986. Chemical geodynamics. Annu. Rev. Earth Planet. Sci., 14:493-571.

Date of initial receipt: 8 January 1990

Date of acceptance: 24 November 1990

Ms 120B-116 